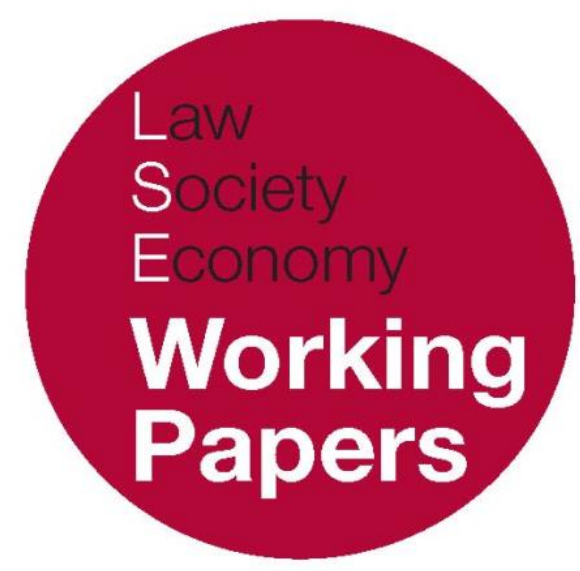

\title{
On Trust: The UN as Fiduciary (A Reply to Rosa Freedman)
}

\author{
Devika Hovell
}

forthcoming in the European Journal of International Law

LSE Law, Society and Economy Working Papers 13/2018 London School of Economics and Political Science

\author{
Law Department
}

\begin{abstract}
This paper can be downloaded without charge from LSE Law, Society and Economy Working Papers at: www.lse.ac.uk/collections/law/wps/wps.htm and the Social Sciences Research Network electronic library at: http://ssrn.com/abstract $=3204151$.

(c) Devika Hovell. Users may download and/or print one copy to facilitate their private study or for non-commercial research. Users may not engage in further distribution of this material or use it for any profit-making activities or any other form of commercial gain.
\end{abstract}




\title{
On Trust: The UN as Fiduciary (A Reply to Rosa Freedman)
}

\author{
Devika Hovell *
}

\begin{abstract}
In the literature responding to the problem of sexual violence by UN peacekeepers, scholars have focused on 'shame', 'danger' and even 'hope' as values around which to frame accountability processes. The premise of this article is that the UN's failure to prevent sexual abuse and exploitation by peacekeepers is primarily a betrayal of trust, such that one of the central roles of accountability processes should be to work to repair and restore trust. Of course, the concept of trust is context specific and can have interpersonal, financial and political manifestations and implications. It also has legal relevance. I argue that trust is foundational to our understanding of the legal authority exercised by UN peacekeepers. In legal terms, we can classify the relationship between UN peacekeepers and the foreign populations over which they exercise authority in the nature of a fiduciary relationship. Because the fiduciary relationship is legal in nature, it generates legal duties, including the duty to account to those over whom it exercises control.
\end{abstract}

\footnotetext{
* Associate Professor in Public International Law, London School of Economics and Political Science.
} 
No other continent has endured such an unspeakably bizarre combination of foreign thievery and foreign goodwill.

- Barbara Kingsolver, The Poisonwood Bible

Sexual abuse is a very human stain that has marked many organizations that define themselves through virtue, including the church, schools, scouting organizations and other humanitarian organizations. The exposure of sexual abuse by United Nations (UN) peacekeepers reveals behaviour that is undoubtedly unconscionable, but surely not inconceivable. While the UN was constructed from plans to deliver peace, security, development and human rights, the organization was inescapably hewn from the crooked timber of humanity. The UN is ultimately a creature of the world upon which it seeks to act. The reality of sexual abuse by UN peacekeepers has been destructive of the organization's legitimacy, yet so is any fantasy about the imagined purity of the organization and its personnel. Scholarly attention to the development of an accountability framework for UN peacekeeping is critical so as to avoid not only overly romantic, but also overly cynical, readings of the nature of the organization.

In an article forthcoming in the European Journal of International Law, Rosa Freedman calls for a 'new approach to accountability' in response to sexual abuse by UN peacekeepers. ${ }^{1}$ Her focus is on accountability as a process rather than a value. Freedman highlights the importance of a victim-centred approach, arguing for the need to place relevant aspects of criminal justice, truth and reconciliation, human rights and political processes at the heart of accountability responses. In this short article, my focus will be on the currency, rather than the metal, of the accountability coin, giving regard to the value or values we expect accountability to serve in this setting rather than to its processes. It is hoped that this will provide an interesting foundation to support, but also to critique, elements of Freedman's discussion.

History tells that the humanitarian nature of an institution or authority is no antidote to misdeed. Certainly for the countries in which the highest number of UN sexual abuse allegations has been recorded (Haiti, the Central African Republic, the Democratic Republic of the Congo and South Sudan), the history of humanitarianism is also a history of paternalism. Both 'isms' involve 'the act of interfering in the lives of others, often without their permission, on the grounds that such interventions are for their own good'. ${ }^{2}$ In order to avoid one sliding into the other, humanitarians must navigate a delicate balance between care and control. Michael Barnett has tracked the history of humanitarianism, drawing chilling comparisons between the 'civilizing mission' of empire and liberal humanitarianism. ${ }^{3}$ Of course, there is also a key normative distinction between these

${ }^{1}$ Freedman, 'UNaccountable: A New Approach to Peacekeepers and Sexual Abuse' (forthcoming,

European Journal of International Law).

${ }^{2}$ M. Barnett, Empire of Humanity (2011), at 233.

${ }^{3}$ Ibid. 
projects. To effectively distinguish itself from imperial governance, humanitarian governance must stake its legitimacy on purpose: to act for the benefit of the ruled rather than of the rulers. The legitimacy of humanitarian governance is dependent on the idea that humanitarian agencies act not out of self-interest but, rather, as a public trustee and for the benefit of the ruled.

At the heart of the relationship, therefore, is trust. In the literature responding to the problem of sexual violence by UN peacekeepers, scholars have focused on 'shame', 'danger' and even 'hope'. ${ }^{4}$ My argument is that 'trust', at least from an institutional perspective, is the key institutional value that is betrayed by reported (and unreported) cases of sexual abuse by UN peacekeepers and is the value that accountability processes must seek to restore. Of course, the concept of trust is context specific and can have interpersonal, financial and political manifestations and implications. ${ }^{5}$ It also has legal relevance. I argue that trust is foundational to our understanding of the legal authority exercised by UN peacekeepers. In legal terms, we can classify the relationship between UN peacekeepers and the foreign populations over which they exercise authority in the nature of a fiduciary relationship. Because the fiduciary relationship is legal in nature, it generates legal duties, including the duty to account to those over whom it exercises control.

\section{THE VERY DISAPPOINTING HISTORY OF INTERNATIONAL TRUSTEESHIP}

The notion of trusteeship can be traced (though, evidently, the notion was not passably implemented) to the time of the British Empire. The origins of trusteeship have been attributed to Edmund Burke in his attempt to place colonial rule on a humanitarian footing. ${ }^{6}$ Following the dissolution of the East India Company, there was 'a shift in ideology justifying Empire from the vulgar language of profit to that of order, proper governance and humanitarianism'. ${ }^{7}$ In Burke's famous speech on the (ultimately defeated) East India bill of 1783, he noted:

All political power which is set over men, and that all privilege claimed or exercised in exclusion of them, being wholly artificial, and for so much a derogation from the natural equality of mankind at large, ought to be some way

\footnotetext{
${ }^{4}$ Engle, 'The Grip of Sexual Violence: Reading UN Security Council Resolutions on Human Security' and Shepherd, 'The Road to (and from) "Recovery": A Multidisciplinary Feminist Approach to Peacekeeping and Peacebuilding', both in G. Heathcote and D. Otto, Rethinking Peacekeeping, Gender Equality and Collective Security (2014).

${ }^{5}$ Harding, 'Manifesting Trust', 29 Oxford Journal of Legal Studies (2009) 245, at 246.

${ }^{6}$ Though Ralph Wilde notes that the concept is also evident in the ideas of Francisco de Vitoria and Bartolome de Las Casas in relation to Spanish colonialism in the 16th century. Wilde, 'From Trusteeship to Self-Determination and Back Again', 31 Loyola and Los Angeles International and Comparative Law Review (2009) 85, at 96.

7 A. Anghie, Imperialism, Sovereignty and the Making of International Law (2005), at 69.
} 
or other exercised ultimately for their benefit. ... [S] uch rights or privileges ... are all in the strictest sense a trust; and it is of the very essence of every trust to be rendered accountable. ${ }^{8}$

This is not the article in which to engage in a full exploration of the developing notion of trusteeship in theory through colonial protectorates, mandates of the League of Nations and, ultimately, trust territories administered through the UN Trusteeship Council - and the extent of its betrayal in practice. This is a task that has been carried out amply by other scholars. ${ }^{9}$ In many respects, the history of trusteeship is one of perversion of the concept of trust, contradicting the idea that the trustee is supposed to be acting selflessly in the interests of the beneficiary only and not also for its own sake. ${ }^{10}$ A central critique of colonialism, despite Burke's attempts, is that it was associated explicitly with policies concerning the interests of the colonial state and its settlers. ${ }^{11}$ Less discussed is the extent to which the League of Nations' Mandate system failed to provide adequate protection to vulnerable populations, though examples are well known and easily identifiable. In the South West Africa case, the International Court of Justice determined that League states had no legal right or interest in checking the general well-being of the inhabitants of Mandate territories, including the compliance of the mandatory power with fundamental human rights norms. ${ }^{12}$ This was in spite of the fact Article 22 of the Covenant of the League of Nations describes the well-being and development of peoples in Mandate territories as forming a 'sacred trust of civilization'. ${ }^{13}$

In previous eras, the international legal conception of 'sovereignty' stood between trustee states and the rights of the populations with which such states were supposedly 'entrusted'. Trusteeship remained a limited notion in an era in which controlled or 'trust' territories were not sovereign, meaning that virtually no legal restrictions were imposed on the actions of administering powers with respect to the peoples living within them. In the colonial era, any restrictions on the actions of imperial powers towards colonial territories resulted from conflicts between imperial states regarding the same territory, not from any rights on the part of

\footnotetext{
${ }^{8}$ Burke, 'Speech on Fox's East India Bill (1783)', in The Writings and Speeches of Edmund Burke (1901), vol. 2, at 439, cited in Boisen, 'The Changing Moral Justification of Empire: From the Right to Colonise to the Obligation to Civilize', 39(3) History of European Ideas (2013) 335, at 346.

9 See, e.g., Fitzmaurice, 'Sovereign Trusteeship and Empire', 16 Theoretical Inquiries in Law (2015) 447; R. Wilde, International Territorial Administration: How Trusteeship and the Civilizing Mission Never Went Away (2008); B. Ibhawoh, Imperialism and Human Rights: Colonial Discourses of Rights and Liberties in African History (2006); Anghie, supra note 6; A.W. Brian Simpson, Human Rights and the End of Empire: Britain and the Genesis of the European Convention (2001), ch. 6; S. N'zatioula Grovogui, Sovereigns, Quasi-Sovereigns and Africans (1996); K. Robinson, The Dilemmas of Trusteeship: Aspects of British Colonial Policy between the Wars (1965).

${ }^{10}$ Wilde, 'Understanding the International Territorial Administration Accountability Deficit: Trusteeship and the Legitimacy of International Organizations', 12 Journal of International Peacekeeping (2008) 93, at 107.

${ }^{11}$ W. Bain, Between Anarchy and Society: Trusteeship and the Obligations of Power (2003).

12 South West Africa (Ethiopia v. South Africa; Liberia v. South Africa), Second Phase, Judgment [1966] ICJ Rep. 51. See Dugard, ' 1966 and All That: The South West Africa Judgment Revisited in the East Timor Case', 8 African Journal of International and Comparative Law (1996) 549, at 550.

${ }^{13}$ Covenant of the League of Nations 1919, 13 AJIL Supp. 128 (1919).
} 
colonial territories or their populations. ${ }^{14}$ Even in the South West Africa case, the ICJ concluded that considerations of state sovereignty and strict adherence to the requirement of consent to adjudication should prevail over wider community interests in the advancement of human rights.

For an understanding of 'trust' that might guide us in the modern era, we must look to the future not the past. The concept of trust is central to explaining how UN peacekeeping should be rendered accountable, while the history of trusteeship is perhaps best understood as a means to educate us as to why this has not happened properly.

\section{THE UN AS FIDUCIARY}

At its inception, UN peacekeeping was a consensual, non-interventionist, noncoercive military activity. ${ }^{15}$ No longer. Following the end of the Cold War, so-called multi-dimensional peacekeeping operations have become typical, frequently involving a significant peace-building component, which can include operating, strengthening and rebuilding state institutions. ${ }^{16}$ The UN Handbook on UN Multidimensional Peacekeeping Operations acknowledges that peacekeeping operations may be required to ' $[a]$ dminister a territory for a transitional period, thereby carrying out all the functions that are normally the responsibility of a government'. ${ }^{17}$ Frédéric Mégret and Florian Hoffman have labelled these operations 'the new protectorates' in recognition that some peace operations have transformed into fully-fledged international administrations. ${ }^{18}$

The enormity of this potential mandate should lead us to inquire into the basis for UN peacekeeping authority. It is clear that UN peacekeepers cannot claim political authority to perform public functions on behalf of a population, in the sense of authority derived from the consent of the peoples in relation to whom they act. Technically, peacekeeping forces are deployed on the basis of the consent of the host state, normally reflected in the negotiation and adoption of a status-offorces agreement between the UN and a host state. ${ }^{19}$ However, given that peacekeeping forces most often operate in volatile or weak post-conflict states, characterized by the collapse or degradation of state structures, anything close to

\footnotetext{
14 Anghie, supra note 6, at 103.

15 White, 'Peacekeeping and International Law', in J. Koops et al., Oxford Handbook of United Nations Peacekeeping Operations (2015) 43, at 44.

16 Report of the Panel of UN Peace Operations, UN Doc. S/2000/809, 21 August 2000; S. Chesterman, You, the People: The United Nations, Transitional Administration and State-Building (2005), at 4-5; Chopra, 'Introducing Peace Maintenance', 4 Global Governance (1998) 1.

17 Department of Peacekeeping Operations, Handbook on UN Multidimensional Peacekeeping Operations, December 2003, available at https://peacekeeping.un.org/sites/default/files/peacekeepinghandbook_un_dec2003_0.pdf.

18 Mégret and Hoffman, 'The UN as Human Rights Violator? Some Reflections on the United Nations Changing Human Rights Responsibilities', 25 Human Rights Quarterly (2003) 314, at 327.

19 White, supra note 14 , at 48.
} 
informed consent of the local populations becomes improbable. As stated in the UN Department of Peacekeeping Operations' Principles and Guidelines, ' $[\mathrm{t}] \mathrm{he}$ fact that the main parties have given their consent to the deployment of a United Nations peacekeeping operation does not necessarily imply or guarantee that there will also be consent at the local level, particularly if the main parties are internally divided or have weak command and control systems'. ${ }^{20}$

UN peacekeeping forces do not exercise political authority, implicating as this does the idea of political representation. The authority of UN peacekeepers is best described as legal, rather than political, in nature, derived from legal, rather than political, sources. The foundation of UN peacekeeping authority is the UN Charter, including Chapters 6, 7 and 8 and, more specifically, the UN Security Council resolution(s) establishing its mandate. ${ }^{21}$ In turn, the scope of this mandate is tied inextricably to the purposes of the UN. In the Certain Expenses case, the ICJ found that, as long as peacekeeping operations fulfilled one of the stated purposes of the $\mathrm{UN}$, the presumption is that such action is not ultra vires the organization. ${ }^{22}$ The authority of UN peacekeeping forces is based on the expectation that they will carry out certain legally authorized purposes and functions.

So far, this says nothing new. Functionalism is the traditional measure of the legality of the conduct of international institutions, connecting legality to fulfilment of an institution's mandated functions. ${ }^{23}$ However, the inadequacy of functionalism to explain the scope of UN authority, particularly in relation to international organizations of general jurisdiction, has also been persuasively argued. Felix S. Cohen compared functionalism in law to functionalist architecture, which is 'likewise a repudiation of outworn symbols and functionless forms that have no meaning - hollow marble pillars that do not support, fake buttresses, and false fronts'. ${ }^{24}$ Drawing on Cohen's work, Anne Orford notes that, just as positivism left the law homeless in Weimar Germany, so functionalism has left international law 'subjectless and thus homeless'. ${ }^{25}$ As Jan Klabbers has identified, functionalism is a principal-agent theory, where the principal (the member states) assigns a set of functions to an agent (the international organization) and has little to say about relations with actors other than those member states. ${ }^{26}$ The delineation of UN

${ }^{20}$ UN Department of Peacekeeping Operations, Principles and Guidelines (2008), at 32, available at www.un.org/en/peacekeeping/documents/capstone_eng.pdf; see also Gray, 'Host State Consent and United Nations Peacekeeping in Yugoslavia', 7 Duke Journal of International Law and Policy (1996) 241. 21 Ibid., at $13-14$.

${ }^{22}$ Certain Expenses of the United Nations, Advisory Opinion, 20 July 1962, ICJ Reports (1962) 151, at 168. 23 Virally, 'La notion de function dans la théorie de l'Organisation internationale', in Mélanges offerts à Charles Rousseau: La Communauté internationale (1974) 277; Mitrany, 'The Functional Approach to World Organization', 24 International Affairs (1948) 350, at 351; Klabbers, 'The Emergence of Functionalism in International Institutional Law', 25 European Journal of International Law (EJIL) (2014) 645.

24 Cohen, 'Transcendental Nonsense and the Functional Approach', 35(6) Columbia Law Review (1935) 809, at $822-823$.

25 A. Orford, International Authority and the Responsibility to Protect (2011), at 195.

${ }^{26}$ Klabbers, 'Functionalism, Constitutionalism and the United Nations', in A.F. Lang and A. Wiener (eds), Research Handbook on Global Constitutionalism (2017) 358. 
functions says nothing about the proper subjects of UN authority, the standards or principles by which its actions may be assessed or the means by which it may be held to account.

Recognition of the foundation of UN peacekeeping authority in law has consequences beyond those identified by functionalist theory. Where the law entrusts irresistible discretionary power over the interests of another party interests that are vulnerable by virtue of that power - this establishes a relationship premised on a presumption of trust. The basis of this authority is the controlling authority's subjection to, and compliance with, the requirements of the trust-like position in which it stands vis-à-vis its legal subjects. Such a presumption renders the controlling authority's exercise of power justifiable to the beneficiary, for it is on trust (rather than the beneficiary's consent) that the authority depends. One way of thinking about this trust-like relationship in legal terms is to recognize a fiduciary relationship. Here, I draw on a growing body of literature that characterizes the relationship between state or state-like institutions and those subject to their authority as fiduciary in nature. ${ }^{27} \mathrm{~A}$ fiduciary relationship arises where one party holds discretionary power of an administrative nature over the important interests of another and this latter party (the beneficiary) is unable, either as a matter of fact or law, to control or exercise the power held by the fiduciary. ${ }^{28}$ The relationship is premised on the idea that the vesting of legal authority would be frustrated if the authorized party could act without due regard for the other's interests and the purpose for which the authority is granted. As Evan Fox-Decent explains, ' $[t]$ he beneficiary's trust may be thought of as an unarticulated and legitimate expectation that the fiduciary's power will be exercised on her behalf and for her ends, rather than say for the sake of the fiduciary's ends'. ${ }^{29}$

The notion of trust provides a foundation for an accountability framework for UN peacekeeping. Fiduciary theory is fundamentally legal and relational, offering a method to explain what it means for institutions to hold and exercise public authority on behalf of others. ${ }^{30}$ The recognition of fiduciary obligations renders the fiduciary liable to the beneficiary should the fiduciary breach them. The concept of public institutions as fiduciaries is a topic that I can only begin to tackle in this article, though it is an idea that others have taken the time to explore in more detail, particularly in the context of state institutions. ${ }^{31}$ My sense is that the fiduciary architecture can orient us in figuring out the scope of UN accountability in cases of

${ }^{27}$ D. Gordon Smith, G.L. Farr and A.S. Gold, Research Handbook on Fiduciary Law (forthcoming); D. Vitale, 'Trust and the Administration of Social Welfare Entitlements' (2018) (PhD thesis on file at London School of Economics); E. Fox-Decent, Sovereignty's Promise: The State as Fiduciary (2011); E. Criddle and E. Fox-Decent, Fiduciaries of Humanity (2016); Leib, Ponet and Serota, 'Translating Fiduciary Principles into Public Law', 126 Harvard Law Review Forum (2013) 91; Finn, 'The Forgotten "Trust": The People and the State', in M. Cope (ed.), Equity: Issues and Trends (1995) 131.

${ }^{28}$ Fox-Decent, supra note 26, ch. 4.

${ }^{29}$ Ibid., at 243.

30 Criddle and Fox-Decent, supra note 26, at 352.

31 Of particular relevance in international terms are Criddle and Fox-Decent, supra note 26; Benvenisti, 'Sovereigns as Trustees of Humanity: On the Accountability of States to Foreign Stakeholders', 107(2) American Journal of International Law (AJIL) (2013) 295. 
sexual abuse by UN peacekeepers. It has been argued that it provides a legal basis for institutional accountability in cases relating to the sexual abuse of Aboriginal children in Indian residential schools ${ }^{32}$ and sexual misconduct by clergy against parishioners. ${ }^{33}$ While it is necessary to distinguish institutional from individual accountability, institutional claims for breach of fiduciary duty may arise out of an organization's failure to investigate allegations of wrong, its failure to warn potential victims or its failure to take earlier remedial action against known wrongdoers.

By putting trust at the heart of the legal relationship, it also becomes important to ensure that accountability frameworks strengthen, and do not in themselves corrode, public trust in an institution. A range of scholars have recognized the capacity for overly intrusive forms of accountability and regulation to become counter-productive or debilitating, driving out opportunities for trusting relationships and reducing the level of performance in the very area they are supposed to effect. ${ }^{34}$ Fiduciary theory looks to "create room for relationships to breathe to help avoid "crowding out" ... trust'. ${ }^{35}$ For example, the focus should be on institutional design rather than on judicial micromanagement so as to nurture a relationship with the organization rather than encouraging beneficiaries to seek recourse outside it. In terms of accountability following organizational crisis, continuing trust in the organization is best served where the organization carries out the therapeutic work of publicly acknowledging the plight of those experiencing risk, harm and trauma, the diagnostic work of truth telling, the inquisitorial work of establishing responsibility and the reconstructive work of lesson drawing. ${ }^{36}$ The quest is for 'meaningful' accountability, with the aim being to support the intelligent placement - and refusal - of trust. ${ }^{37}$

\section{DEVELOPING AN ACCOUNTABILITY FRAMEWORK: TRUST IN THE BALANCE}

In her article, Freedman determines that the ad hoc evolution and policies governing such activities and personnel has contributed to a crisis of accountability for harms caused by peacekeepers'. She acknowledges problems in holding the UN

\footnotetext{
32 Cloud v. Canada, (2004) 73 OR(3d) 401, para. 12, 247 DLR (4th) 667; Blackwater v. Plint, 2005 SCC 58, para. 61, [2005] 3 SCR 3; Bonaparte v. Canada, (2003) 64 OR 3d 1, para. 21.

33 Martinelli v. Bridgeport Roman Catholic Diocesan Corp., 196 F.3d 409, at 426-30 (2d Cir. 1999); Doe v. Evans, 814 So. 2d 370 (Fla. 2002).

34 O'Neill, 'Trust, Trustworthiness and Accountability', in N. Morris and D. Vines, Capital Failure:

Rebuilding Trust in Financial Services (2014); Pettit, 'The Cunning of Trust', 24(3) Philosopby and Public Affairs (1995) 202; Leib, Ponet and Serota, supra note 26.

35 Leib, Ponet and Sorota, supra note 26, at 100.

${ }^{36}$ Kuipers and Hart, 'Accounting for Crises', in M. Bovens, R.E. Goodin and T. Schillemans, Oxford

Handbook of Public Accountability (2014) 589, at 600.

37 O’Neill, supra note 33, at 180; Bovens and Schillemans, 'Meaningful Accountaiblity', in Bovens, Goodin and Schillemans, supra note 35, 673 .
} 
to account given the scope of existing immunities and uncertainty over the extent to which the UN is bound by international human rights law. Against this uncertain legal landscape, her proposal for a 'holistic and victim-centred approach' to accountability is essentially policy based. My hope in outlining the above is to provide a normative foothold for the regime she proposes. Additionally, the recognition of the fiduciary obligations of the UN provides a basis upon which to elaborate, but also to delimit, the scope of UN accountability in the peacekeeping setting.

One of Freedman's main accountability aims is to promote a 'human rightsbased approach'. Yet, in exploring the parameters of this possibility legally, her focus is on the relationship between UN immunity and human rights. To my mind, this casts the accountability problem too narrowly. The question of accountability implicates a broader problem than the immunity of the UN and its institutions before domestic courts. By focusing on the capacity to bring the UN before domestic courts, there is a danger in overlooking the more fundamental legal concern that the UN considers ensuring human rights protections for administered populations is essentially a policy decision rather than something the UN is legally bound to do. As the independent ombudsperson in Kosovo declared in relation to failures by the UN Interim Administration Mission in Kosovo to ensure the Kosovar population were granted human rights protections, '[i]t is ironic that the United Nations, the self-proclaimed champion of human rights in the world, has by its own actions placed the people of Kosovo under UN control, thereby removing them from the protection of the human rights regime that formed the justification for UN engagement in Kosovo in the first place'. ${ }^{38}$ In developing a legal foundation for accountability frameworks, fiduciary theory can do important work. The recognition of the UN's fiduciary relationship with populations under its administration provides a legal basis for accountability if the UN fails to take adequate measures to prevent and protect such populations from human rights violations. ${ }^{39}$

Many of the accountability frameworks proposed by Freedman are drawn from the international criminal setting. One problem with this approach is highlighted by Freedman herself who recognizes that 'accountability in relation to UN peacekeepers must... go beyond traditional calls solely for criminal law processes'. The top-down case management model which remains dominant in the context has its limitations. Westendorf has written persuasively about the danger of focusing too heavily on procedures for the investigation and prosecution of allegations, reinforcing an individualised conduct and discipline approach and thereby failing to

\footnotetext{
38 Ombudsperson Institution in Kosovo, Second Annual Report (2001-2002), at 5, available at www.ombudspersonkosovo.org/repository/docs/E6020710a_845763.pdf.

${ }^{39}$ For an alternative legal analysis, see Roísín Burke's focus on due diligence, which directs attention to the troop-contributing state rather than the United Nations as the source of accountability: 'Shaming the State: Sexual Offences by UN Military Peacekeepers and the Rhetoric of Zero Tolerance' in Heathcote and Otto, supra note 4.
} 
address the complex mix of permissive and motivating factors that give rise to sexual exploitation and abuse. ${ }^{40}$

The underlying notion of trust might also lead us to question some of the more exaggerated demands Freedman makes of accountability. The call for an internationalized hybrid tribunal and truth commission draw on international criminal justice and transitional justice models of accountability designed to move whole societies on from regimes under whose banner populations have been subjected to gross violations of human rights. Account must be taken of the significant costs of setting up these bodies to ensure that they do not disproportionately overburden the organization and siphon critical resources from other UN operations. Other problems with the international criminal law model are highlighted by Freedman's claim that UN failure to prevent sexual misconduct by peacekeepers 'amount [s] to torture'. I accept that the allegation is not that the UN has itself engaged in acts of torture in violation of the prohibition, but that is has violated the obligation under Article 2 of the Convention to prevent torture. The Committee Against Torture's General Comment No 2 confirms that 'each State party should prohibit, prevent and redress torture...in all contexts of custody or control', including in 'peacekeeping operations'. ${ }^{41} \mathrm{My}$ problem here is not so much with the idea that the UN has an obligation to prevent torture, but with the potential distortion entailed in broadly classifying sexual misconduct by peacekeepers as torture. The evidence does not support the suggestion that the majority of sexual abuse was carried out as an intentional policy to obtain information, punish, intimidate or discriminate against individuals, as the definition of torture requires. ${ }^{42}$ Jasmine-Kim Westendorf and Louise Searle conducted a review in which they recognize that the range of sexual exploitation and abuse perpetrated by peacekeepers is diverse and driven by different motivating factors, encompassing opportunistic sexual exploitation, transactional sex, networked sexual exploitation as well as planned, sadistic attacks. ${ }^{43}$ The 2005 Zeid report, which was commissioned by the UN to provide a comprehensive investigation of peacekeeper abuse, shows that, at least in the Democratic Republic of the Congo, the majority of allegations relate to transactional sex, including the exchange of sex for money, food and jobs. ${ }^{44}$

\footnotetext{
40 Westendorf, 'WPS, CRSV and sexual exploitation and abuse in peace operations: making sense of the missing links', LSE Women, Peace and Security Working Paper Series, 9/2017 (2017), available at http://eprints.lse.ac.uk/85992/1/WP9_2017.pdf. ${ }^{41}$ Committee Against Torture, General Comment No. 2, UN Doc. CAT/C/GC/2 (24 January 2008), paras 15-16.

42 Convention against Torture and Other Cruel, Inhuman or Degrading Treatment or Punishment 1984, 1465 UNTS 85, Art. 1

43 Westendorf and Searle, 'Sexual Exploitation and Abuse in Peace Operations: Trends, Policy Responses and Future Directions', 93(2) International Affairs (2017) 365.

${ }^{44}$ Zeid Ra'ad Zeid Al-Hussein, A Comprehensive Strategy to Eliminate Future SEA in UN Peacekeeping Operations, UN Doc. A/59/710 (2005), para. 6.
} 
That is not to say that there are no individual instances of sexual abuse by UN peacekeepers that might be classified as torture. ${ }^{45}$ While not seeking in any way to repudiate or diminish the need for the UN to account for incidents of sadistic abuse and to deploy all reasonable means to prevent future incidents, the holistic characterization of peacekeeper sexual misconduct as torture, and the development of accountability frameworks based on the characterization of the relevant conduct as torture, requires careful consideration and justification. It is important that accountability frameworks target all forms of sexual misconduct, including but not limited to torture. As Freedman herself emphasizes, a critical aspect of accountability is that those affected have a right to have their stories told. Heathcote has written about the danger of reinforcing the stereotype of the non-Western victim subject, to whom restricted agency and seemingly perpetual vulnerability are attributed. ${ }^{46}$ The source of the 'problem' becomes located in the personality of the victim population, implicitly questioning its capacity for agency and selfgovernment. ${ }^{47}$ It is clearly important to distinguish between legal consensual sex, commercial prostitution, 'survival sex' and serious criminal offences of a sexual nature, such as abuse of children, rape and torture. Law must seek to use language that most accurately identifies the crime and its nature. ${ }^{48}$ Legal language 'reinforces certain world views and understandings of events ... Through its definitions and the way it talks about events, law has the power to silence alternative meanings - to suppress other stories'. ${ }^{49}$ It is important to recognize rape as torture where appropriate ${ }^{50}$ but it is also important to recognize rape as rape and for accountability frameworks to provide scope to understand the particular nature of the UN's failings in relation to sexual exploitation and abuse by UN peacekeepers.

The importance of not mischaracterizing the nature of the UN's wrongdoing is significant not just for victims but also for the preservation and protection of international legal structures including international criminal law and, indeed, the UN itself. In 2010, against the backdrop of the emerging scale of sexual abuse against minors by Catholic priests, Geoffrey Robertson made headlines when he claimed that Pope Benedict XVI could be 'put in the dock' for crimes against humanity and might bear command responsibility for widespread and systematic

\footnotetext{
${ }^{45}$ Indeed, a leaked internal 2015 UN report documents instances (less common, though not isolated) of rape for the sadistic pleasure of the perpetrators, involving both planning and coordination. These instances include allegations of the oral and anal rape of homeless and starving boys aged 8 to 15 by 26 peacekeepers from France, Chad and Equatorial Guinea and the beating and rape of a teenage boy by Canadian peacekeepers in Somalia: Westendorf and Searle, supra note 43, at 370.

${ }^{46}$ Heathcote, 'Participation, Gender and Security' in Heathcote and Otto, supra note 4, at 50.

47 Pupavac, 'War on the couch: The emotionology of the new international security paradigm', 7(2) European Journal of Social Theory (2004) 149, at 163.

48 Askin, 'Sexual Violence in Decisions and Indictments of the Yugoslav and Rwandan Tribunals: Current Status', 93 AJIL (1999) 97, at 101, n. 31; Askin, War Crimes against Women: Prosecution in International War Crimes Tribunals (1997), at xv; Chinkin, 'Rape and Sexual Abuse of Women in International Law', 5 EJIL (1994) 326, at 329, n. 22.

${ }^{49}$ Finley, 'Breaking Women's Silence in Law: The Dilemma of the Gendered Nature of Legal Reasoning', 64 Notre Dame Law Review (1989) 886, at 888, cited in Sivakumaran, 'Sexual Violence against Men in Armed Conflict', 18(2) EJIL (2007) 253.

${ }^{50}$ M. Peel, Rape as a Method of Torture (2004).
} 
molestation of children by priests in the Catholic Church. ${ }^{51}$ While these claims attract headlines and may be effective in terms of advocacy, they also serve to dilute and distort important legal categories that must be preserved in order to effectively identify and target particular types of harm in international society. Inappropriate or disproportionate accountability frameworks do not aid the task of reconciliation and can serve instead to alienate and divide sympathies in a way that does not ultimately serve victims. In terms of the UN, misplaced claims that it has engaged in torture would also have a destructive effect on its future effectiveness. The aim of accountability mechanisms is to restore trust, not to erode it further by mischaracterizing the failure to prevent sexual exploitation by peacekeepers as institutionally mandated torture.

\section{CONCLUSION}

In her article, Freedman lays down an important challenge to develop a new approach to accountability. She concludes by recognizing that much about accountability for sexual abuse by UN peacekeepers remains unclear, leaving unanswered critical questions such as 'what accountability looks like and who needs to be accountable to whom and in what matter'. My proposal is to add the preliminary question of 'why' to the mix, not out of any doubt that accountability is due but, rather, to guide us in answering Freedman's concluding questions. In this brief article, I argue that the UN's failure to prevent sexual abuse and exploitation of peacekeepers is primarily a betrayal of trust, such that one of the central roles of accountability processes should be to work to repair and restore trust. ${ }^{22}$ The UN flag should not be used as a veil against accountability, but nor should it make the UN an indiscriminate target. Accountability frameworks should serve to make an organization such as the UN more robust, rather than unwittingly serving further to undermine it.

51 G. Robertson, 'Put the Pope in the Dock', The Guardian (2 April 2010), available at www.theguardian.com/commentisfree/libertycentral/2010/apr/02/pope-legal-immunity-internationallaw.

52 Tellingly, the Report of the Independent Review on Sexual Exploitation and Abuse by International Peacekeeping Forces in the Central African Republic (2015), available at www.un.org/News/dh/infocus/centafricrepub/Independent-Review-Report.pdf, commences with the charge: 'Where peacekeepers exploit the vulnerability of the very people they have been sent to protect by sexually abusing members of the local population, it is a fundamental betrayal of trust. When the United Nations (the "UN" or "Organization") fails to address such crimes quickly and decisively, that betrayal is compounded and the important contributions of peacekeeping missions are undermined.' 